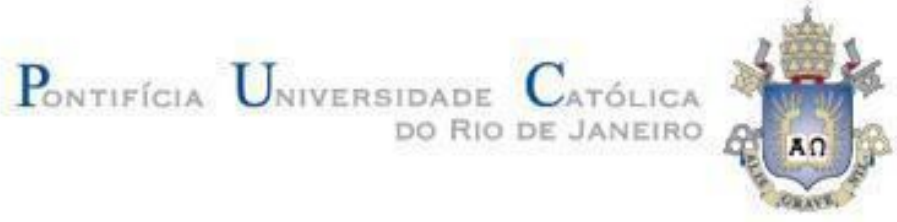

Sérgio Ricardo Schultz

\title{
Propriedade, Propriedade Negada e Negação predicativa: \\ Aspectos Lógicos e Ontológicos da negação
}

Tese de Doutorado

Tese apresentada como requisito parcial para obtenção do título de Doutor pelo Programa de PósGraduação em Filosofia da PUC-Rio.

Orientador: Oswaldo Chateaubriand Filho 


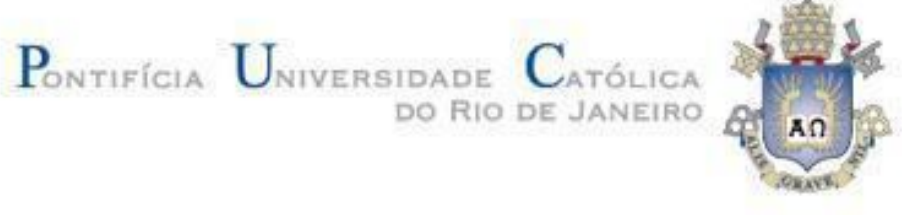

Sérgio Ricardo Schultz

\title{
Propriedade, Propriedade Negada e Negação predicativa:
}

\author{
Aspectos Lógicos e Ontológicos da negação
}

\begin{abstract}
Tese apresentada como requisito parcial para obtenção do título de Doutor pelo Programa de Pós-Graduação em Filosofia da PUC-Rio. Aprovada pela Comissão Examinadora abaixo assinada.
\end{abstract}

\author{
Prof. Oswaldo Chateaubriand Filho \\ Orientador \\ Departamento de Filosofia - PUC-Rio \\ Prof. Luis Carlos Pinheiro Dias Pereira \\ Departamento de Filosofia - PUC-Rio
}

Prof. Ludovic Soutiff

USP

Prof. Abel Lassalle Casanave

UFSM

Prof. Oscar Miguel Esquisabel

Universidad Nacional de La Plata - CONICET - UNQ

Prof. Paulo Fernando Carneiro de Andrade Coordenador(a) Setorial do Centro de Teologia e Ciências Humanas - PUC-Rio

Rio de Janeiro, 9 de abril de 2010 
Todos os direitos reservados. É proibida a reprodução total ou parcial do trabalho sem autorização da universidade, do autor e do orientador.

\section{Sérgio Ricardo Schultz}

Graduou-se em Filosofia pela UFSM e concluiu o mestrado em Filosofia pela mesma instituição. Suas áreas de interesse são Filosofia da Lógica e da Matemática e Metafísica.

Ficha Catalográfica

Schultz, Sérgio Ricardo

Propriedade, propriedade negada e negação predicativa: aspectos lógicos e ontológicos da negação / Sérgio Ricardo Schultz ; orientador: Oswaldo Chateaubriand Filho. -2010.

$191 \mathrm{f}$; $30 \mathrm{~cm}$

Tese (Doutorado em Filosofia)-Pontifícia Universidade Católica do Rio de Janeiro, Rio de Janeiro, 2010.

Inclui bibliografia

1. Filosofia - Teses. 2. Propriedade negada. 3. Negação. 4. Propriedade. 5. Sujeito e predicado. 6. Diferença. I. Chateaubriand Filho, Oswaldo. II. Pontifícia Universidade Católica do Rio de Janeiro. Departamento de Filosofia. III. Título.

CDD: 100 


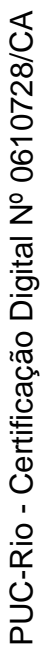

À Juliana Mezzomo Flores, 


\section{Agradecimentos}

Ao meu orientador, prof. Oswaldo Chateaubriand, pela disponibilidade, compromisso, incentivo, e pelas leituras atenciosas e incisivas das versões desta tese.

Ao prof. Abel Lassalle Casanave, pelo apoio constante e infatigável, além dos inúmeros (e sábios) conselhos, sugestões e discussões.

Aos professores Javier Legris e Oscar Miguel Esquisabel, pela amabilíssima recepção em Buenos Aires e em La Plata, pelos cafés, pelas charlas e pelas agradáveis e iluminadores discussões.

Ao prof. Frank Thomas Sautter, pelo incentivo e pelas discussões.

Ao prof. Ronai Pires da Rocha, por ter me introduzido à boa e fora de moda filosofia de Oxford.

À Samir Desbessel Ferreira, Evandro Carlos Godoy e os 'primos' 141 e 141A, pela amizade e bons momentos passados juntos, e também à Hélia Maria Soares de Freitas, Gisele Secco e Bruno Rafaelo Lopes Vaz.

À colega Nastassja Pugliese pelo auxílio com o abstract.

Ao CNPq e à PUC-Rio, cujo financiamento possibilitou o desenvolvimento de minha pesquisa. 


\section{Resumo}

Schultz, Sérgio Ricardo; Chateaubriand, Oswaldo (Orientador). Propriedade, Propriedade Negada e Negação predicativa: aspectos lógicos e ontológicos da negação. Rio de Janeiro, 2010. 191p. Tese de Doutorado - Departamento de Filosofia, Pontifícia Universidade Católica do Rio de Janeiro.

Desenvolvemos na presente tese uma análise de aspectos lógicos e ontológicos concernentes à negação, em especial, aqueles referentes à existência e natureza de propriedades negadas e à relação entre negação e diferença. Partindo da concepção de acordo com a qual propriedades, em contraposição a objetos, são aquelas entidades que correspondem a predicados, propomos uma concepção de propriedades e da relação entre estas e predicados. A seguir, examinamos a distinção entre sujeito e predicado, procurando tornar clara a extensão da noção de propriedade, em particular, se e em que medida podemos afirmar que existem propriedades logicamente complexas como propriedades da forma não-F. Por fim, investigamos o que são propriedades negadas, com ênfase na relação entre as noções de negação, propriedade negada e diferença. Ao longo de nosso trabalho procuramos desenvolver uma concepção de propriedade, negação e propriedade negada partindo da premissa - poucas vezes considerada - de que propriedades são condições de aplicação de predicados e não simplesmente a denotação ou referência de expressões predicativas. Como conseqüência, a noção de propriedade desenvolvida por nós possui estreita ligação não somente com a noção de verdade como também com as noções de falsidade e diferença. Lançamos, assim, uma nova perspectiva sobre a noção de propriedade de acordo com a qual a aceitação de propriedades negadas e sua análise em termos de diferença são desdobramentos naturais da noção geral de propriedade.

\section{Palavras-chave}

Propriedade negada; negação; propriedade; sujeito e predicado; diferença. 


\section{Abstract}

Schultz, Sérgio Ricardo; Chateaubriand, Oswaldo (Advisor). Property, Negated Property and Predicate Negation: logical and ontological aspects of negation. Rio de Janeiro, 2010. 191p. Thesis. Departamento de Filosofia, Pontifícia Universidade Católica do Rio de Janeiro.

In this thesis we develop an analysis of the logical and ontological aspects of negation, and especially, those associated with the existence and nature of negated properties and the relationship between negation and difference. From the idea that properties - contrary to objects - are those entities which correspond to predicates, we offer an understanding of properties and of the relationship between them and predicates. After that, we discuss the distinction between subject and predicate, trying to make clear the scope of the notion of predicate, and if, and to what extent, we can acknowledge the existence of logically complex properties like non-F proprieties. Lastly, we inquire into the nature of denied properties, emphasizing the relationship between the notions of negation, denied property, and difference. Throughout our work we tried to develop a conception of property, negation, and denied property, taking for granted the premise - rarely taken into account - that properties are applicability conditions of predicates, and not merely their denotation or reference. Consequently, the notion of property we have developed is connected not only with the notion of truth, but also with the notions of falsity and difference. Hence, we launch a new perspective over the notion of property, according to which the acceptance of denied properties and the analysis of denied properties in terms of difference are natural consequences of the general notion of property.

\section{Keywords}

Negated property; negation; property; subject and predicate; difference. 


\section{Sumário}

$\begin{array}{ll}\text { Introdução } & 10\end{array}$

1. Propriedade, predicado e diferença 21

1.1. Predicados e propriedades 25

1.2. Predicado, verdade e compromisso ontológico 36

1.3. Compreensão do predicado, conhecimento da propriedade 50

$\begin{array}{ll}\text { 1.4. Propriedade, objeto e diferença } & 61\end{array}$

2. Sujeito e predicado 75

2.1. Sujeito, predicado e função semântica 80

2.2. Sujeito, predicado e forma lógica. 91

2.3. Sentenças complexas, operadores de predicado e predicados complexos. 100

2.4. Proposições e propriedades complexas 112

3. Negação, propriedade negada e diferença 127

3.1. Propriedade e propriedade negada 130

3.2. Negação, diferença e contradição 143

3.3. Negação, terceiro excluído e contradição 157

$\begin{array}{ll}\text { Conclusão } & 174\end{array}$

$\begin{array}{ll}\text { Referências bibliográficas } & 185\end{array}$ 


\section{Lista de tabelas}

Tabela 1: a tabela de verdade de " $\neg$ " 110

Tabela 2: as tabelas de verdade de "^", " " e “ $\rightarrow$ " 111

Tabela 3: os conetivos fortes de Kleene 164 